\title{
An Assessment of the Impact of Exploring Engineering Through An Experiential Learning Course on Student Attraction and Retention
}

\author{
Julio Urbina and Hirak Patangia \\ Donaghey College of Information Science \& Systems Engineering \\ University of Arkansas at Little Rock \\ jvurbina@ualr.edu; hcpatangia@ualr.edu
}

\begin{abstract}
$\underline{\text { Abstract }}$
With funding from National Science Foundation, a project-based experiential course has been introduced at the freshman level to acquaint students with the engineering field, and to attract students into engineering technology from the general pool of undeclared majors at the university. The course also gives the student a head start for success in courses that come later in the curriculum with the expectation that early exposure to various topics in engineering will lead to improved student success and retention. The course has a heavy emphasis on laboratory activities with an equally strong focus on 'just-in-time' theory. The learning platform of the course is a magnetic ball levitator, and the course prepares the students to be able to design and construct the levitator system by the end of the semester. The engineering topics have been selected in a way that they are central to accomplishing the project goal, and the laboratory exercises provide them with the hands-on experience necessary to complete the project.
\end{abstract}

The course has been offered six times so far, and data gathered through course evaluations suggest that it has been a successful course in preparing and exposing students to the field of engineering. Eighty nine percent of the students have indicated that the course 'enhanced their interest in engineering'. The paper presents a preliminary follow-up of our experience with the course and an analysis of data pertaining to student satisfaction and their retention.

\section{Introduction}

Engineering enrollment has seen a steady decline since its peak of 441,000 students in 1983. While students across the globe are competing to enter into engineering schools, only $2 \%$ out of four million high school graduates will enter engineering in US. Such a poor percentage is unacceptable at a time of new economy when technological innovation is central to wealth creation and long-term economic growth. Post 'nine eleven' era demands that more American citizens are attracted to STEM education to insure safety and security of the nation. For high school students to be motivated to enter engineering, the teaching and content of high school mathematics must be refocused. One approach to mitigate this situation is to involve high school mathematics and science teachers in engineering education with the goal that they will be able to use engineering applications in their mathematics curriculum to motivate students into the field of engineering and technology.

The University of Arkansas at Little Rock (UALR) received a NSF planning grant under Bridges for Engineering Education (BEE) Program in 2002 through a collaborative effort between the College of Information Science and Systems Engineering, and the College of Education. The focus of the BEE grant program is to bring together faculties of engineering and education with a view to improving engineering content in K-12 education and also support engineering faculty with educational research innovations in pedagogy. The objective of the UALR BEE grant is to design, develop, and refine a series of 'thematic' engineering courses to bring engineering education to pre-college educators, education majors, high school students, and to any other university student who wants to explore engineering as a career path or enhance technological literacy. Educational research has proven that a rich learning environment contributes tremendously toward improvement in learning achievements and also attitudes toward studies [1]. Such an environment is provided through project based learning [2]. It has been further noted that 
fostering of thinking should be integrated in the learning of a specific context [3]. Project based learning helps develop both lateral and vertical thinking[4,5]. Seeking alternative solutions to project design provides lateral thinking while choosing a solution develops vertical thinking. The BEE course analyzed in this paper has been designed with such a learning philosophy. Although an introductory course, the course was designed to be 'intellectually substantive', and developed on a just-in-time principle [6] in context to a real-world problem. A magnetic ball levitator is the central project (learning platform) of the course.

\section{Overview of the course}

The title of the course is 'Introductory Experience in Technology and Computers' (ECET 1302) and it is a semester long course with two hours of lecture and three hours of laboratory per week. The course has a low barrier in prerequisite and is open to all students at the university. The goal of the course is to focus on the theory and hands-on activities central to completing a final project. The project for the course is the magnetic levitation of a ball in free space, and it requires understanding of electrical and magnetic circuits, optoelectronics, feedback control, and electronic devices. To prepare the students for the project, the following general topics are included in the lecture part of the course: DC and AC analysis; Electronic Devices to include Op-Amps, Transistor Circuits, and Diodes; Magnetics; Optical Electronics, and Feedback Concept. The topics are a vertical integration of four different ECET courses at an introductory level with a focus on fundamentals. Interested readers can view a complete description of the course in $[6,7]$.

\section{$\underline{\text { Evaluations }}$}

The course is limited to thirty students per semester due to limited laboratory seats with two students per station. Based on prior offerings, data have been collected to evaluate the effectiveness of the course to stimulate student interest in the engineering field. Results of a survey return of approximately 120 students relevant to course objectives are shown below. The students are surveyed several times during the progress of the course to determine their difficulties and aptitude for the subject matter. The beginning survey collects background information on the students, which serve as a benchmark, and is used to assign team members. The mid-semester survey assesses their conceptual difficulties, and provides feedback regarding the pace of the course. The final survey has 27 questions and they are designed to evaluate various aspects of the course including course content, course speed, laboratory exercises, homework, quizzes, math usage, in-context learning approach, hands-on experience, and more importantly the motivational aspect of the course. The students are also given the opportunity to give summative comments. Table 1 below summarizes students' affective evaluations to the recruiting, retention, and motivational aspect of the course while Figure 1 gives a visual and percentage representation of these evaluations.

Looking at the student response, it can be concluded that the objectives of the course have been well satisfied. Although the students cannot be definitive about their preparation for future courses, the answers indicate that the course has provided them with confidence for future study in engineering/technology. The course has given them a good understanding of engineering work and they enjoyed the experiential nature of the course. The students overwhelmingly felt that the course has a high degree of recruiting potential of high school students. The course did indeed have some effect on undeclared majors to switch to engineering/technology. A few students decided to change to nonengineering majors, and this is also a positive effect of the course. 
Table 1. Affective Evaluation

\begin{tabular}{|c|c|c|c|c|}
\hline QUESTIONS & & 2002 & 2003 & 2004 \\
\hline \multirow{2}{*}{$\begin{array}{l}\text { 1) The course has given me good prep } \\
\text { for future. }\end{array}$} & AGREE & 37 & 45 & 33 \\
\hline & DISAGREE & 3 & 0 & 2 \\
\hline \multirow{2}{*}{$\begin{array}{l}\text { 2) The course has enhanced my interest } \\
\text { in engineering. }\end{array}$} & AGREE & 32 & 43 & 32 \\
\hline & DISAGREE & 8 & 2 & 3 \\
\hline \multirow{2}{*}{$\begin{array}{l}\text { 3) The course gave a good } \\
\text { understanding of what engineering is } \\
\text { about. }\end{array}$} & YES & 33 & 41 & 27 \\
\hline & $\mathrm{NO}$ & 7 & 4 & 8 \\
\hline \multirow{3}{*}{$\begin{array}{l}\text { 4) Learning theory around a project is } \\
\text { much more interesting }\end{array}$} & AGREE & 24 & 41 & 31 \\
\hline & DISAGREE & 6 & 0 & 0 \\
\hline & NOT SURE & 10 & 4 & 4 \\
\hline \multirow{2}{*}{$\begin{array}{l}\text { 5) I will recommend this course to other } \\
\text { engineering students. }\end{array}$} & YES & 38 & 43 & 34 \\
\hline & $\mathrm{NO}$ & 2 & 2 & 1 \\
\hline \multirow{3}{*}{$\begin{array}{l}\text { 6) Any student with some math } \\
\text { background should be able to handle } \\
\text { the course. }\end{array}$} & YES & 36 & 44 & 32 \\
\hline & & & & \\
\hline & $\mathrm{NO}$ & 4 & 1 & 3 \\
\hline \multirow{2}{*}{$\begin{array}{l}\text { 7) I will recommend any major to try } \\
\text { this course. }\end{array}$} & YES & 22 & 33 & 30 \\
\hline & $\mathrm{NO}$ & $\overline{18}$ & 12 & 5 \\
\hline \multirow{2}{*}{$\begin{array}{l}\text { 8) The course will be good for high } \\
\text { school students in the summer. }\end{array}$} & YES & 35 & 43 & 31 \\
\hline & $\mathrm{NO}$ & 5 & 2 & 4 \\
\hline \multirow{3}{*}{$\begin{array}{l}\text { 9) The course will be good for } \\
\text { recruiting students to engineering. }\end{array}$} & YES & 25 & 37 & 21 \\
\hline & $\mathrm{NO}$ & 5 & 2 & 0 \\
\hline & NOT SURE & 10 & 6 & 14 \\
\hline \multirow{4}{*}{$\begin{array}{l}\text { 10) The course will help me stick with } \\
\text { the engineering field. }\end{array}$} & YES & 18 & 33 & 29 \\
\hline & & & & \\
\hline & $\mathrm{NO}$ & 11 & 1 & 1 \\
\hline & NOT SURE & 11 & 11 & 5 \\
\hline $\begin{array}{l}\text { 11) I decided to switch to engineering } \\
\text { field because of this course. }\end{array}$ & YES & 3 & 2 & 1 \\
\hline $\begin{array}{l}\text { * NO implies students had decided ET as their } \\
\text { major before enrolling. }\end{array}$ & $\mathrm{NO}$ & 37 & 43 & 34 \\
\hline \multirow[t]{2}{*}{ 12) I feel satisfied with the course. } & AGREE & 35 & 44 & 33 \\
\hline & DISAGREE & 5 & 1 & 2 \\
\hline
\end{tabular}




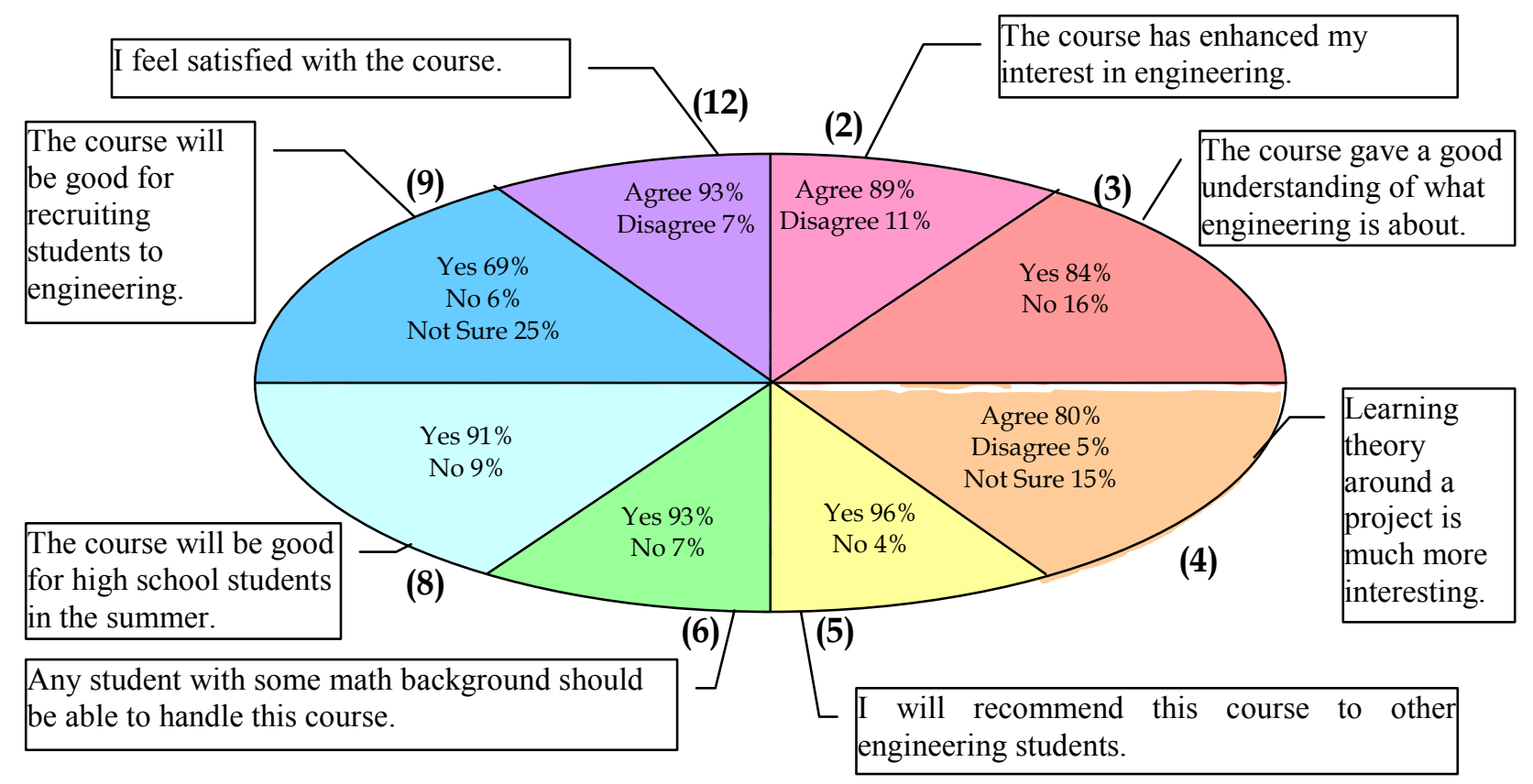

Figure 1. Student Survey

\section{$\underline{\text { Retention }}$}

Our university is a metropolitan university where majority of the students work while going to school. Often their class schedule is determined by their work schedule. As a result, it is difficult to track students' progress since they may drop out of school for a semester or two due to financial or work related reasons. We will require a longer time span to effectively determine student retention rate. However, we have collected data for students who took ECET 1302 in 2002, and the following is an analysis of that data (Figure 2). Out of 48 students who passed 1302 in 2002, 23 continued to Circuit Analysis I (ECET 1404), and they had a success rate of $74 \%$. Fifteen students left the university mainly due to inadequate academic preparations for college. Four students changed their majors while three took the course for technological literacy (personal growth), and possibly the remaining three will continue their education (unaccounted) at a later time.

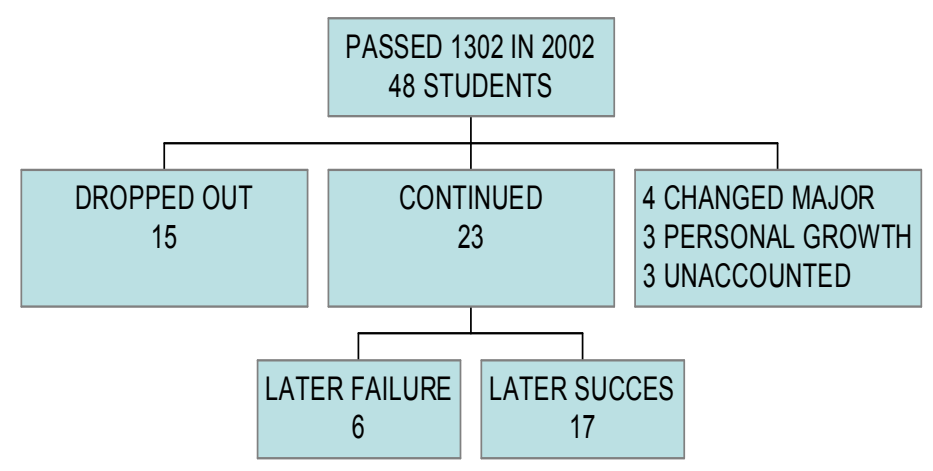

Figure 2. Study of ECET 1302 Data for 2002 
The following table (Table 2) is a summary of the assessment of data for ECET 1302 for the year 2002.

Table 2. 2002 Assessment

\begin{tabular}{|c|c|c|c|}
\hline & PASSED 1302 & RETENTION & LATER SUCCESS \\
\hline SPRING 2002 & 21 & $52 \%$ & $81 \%$ \\
\hline FALL 2002 & 27 & $37 \%$ & $67 \%$ \\
\hline
\end{tabular}

\section{Conclusions}

It has been shown through the implementation of an introductory experiential learning course that a course of this nature has positive impact on: recruiting, student motivation, and students' later success rate. The students' high level of enthusiasm in the course indicates that the course has a strong component in motivating students for further study and attracting undeclared majors to the engineering field. The course has attracted students from diverse fields such as business, psychology, art, computer science, and information systems, although the majority of the students take the course with engineering/technology as their intended major. The students enjoy the laboratory and hands-on project activities of the course, which is a positive characteristic of engineering technology education. The course has been organized more as a 'freshmen success' course, and the students' success rate in the course is high. However, according to our current data, a good percentage of the students shun engineering when they realize the demanding level of mathematical aptitudes and analytical skills necessary to succeed in engineering /technology education. A few have changed majors and some dropped out because of poor academic preparations. Although this observation doesn't help our enrollment, it is good from the students' perspectives in choosing their major and avoiding cost in time and money. Also, our observation has prompted the mathematics department to evaluate their teaching of the algebra courses. The students, who went from this course to the next level of ET courses, had a much higher rate of success than those we had without this course in the past. This is indeed the most positive effect of ECET 1302. Also, it has provided the freshmen a pathway to explore engineering as a career choice.

\section{$\underline{\text { References }}$}

1) J. B. Fraser, J. G. Giddlings, and J. C. McRobbie, "Evolution and Validation Form of an Instrument For Assessing Science Laboratory Classroom Environments", Journal of Research in Science Teaching, 32(4), pp.399-422, 1995.

2) M. Barak and Y. Doppelt, "Promoting Creative Thinking Within Technology Education", Paper presented at the International Workshop for Scholars in Technology Education, WOCATE, George Washington University, Washington DC, September 1998.

3) N. D. Perkins, Technology Meets Constructivism: Do They Make a Marriage?, T. M. Duffy \& H. D. Jonassen Eds., "Constructivism and Technology of Instruction: A Conversation”, ;;.45-55, Hillsdale, NJ, 1992.

4) S. Waks, "Lateral Thinking and Technology Education", Journal of Science Education and Technology, 6(4), pp. 245-255, 1997.

5) E. De Bono, “The CoRT Thinking Program”, $2^{\text {nd }}$ Edition, Oxford: Pergamon Press, 1986.

6) H.C. Patangia, "A Recruiting and Retention Strategy through a Project-Based Experiential Learning Course”, 2003 ASEE Annual Conference (Session 3448); June 22-25, 2003; Nashville, TN. 
7) H. C. Patangia, P. Warrick, N. Jovanovic, and J. Urbina, "Exploring Engineering Through Project Based Experiential Learning For Pre-College Educators", ASEE $3^{\text {rd }}$ International Colloquium on Engineering Education, Beijing, China, 2004.

\section{BIOGRAPHIC INFORMATION}

Julio Urbina received his B.S.Degree from Universidad Nacional de Ingenieria, Lima, Peru, M.S. and $\mathrm{Ph} . \mathrm{D}$ degrees from University of Illinois at Urbana-Champaign. He is an Assistant Professor in the College of Information Science and Systems Engineering at the University of Arkansas at Little Rock

Hirak C. Patangia received his B. Tech. Degree (Honors) from Indian Institute of Technology, Kharagpur, India, M.Sc(Eng) degree from University of New Brunswick, Canada, and Ph.D. degree from McGill University, Canada. He is a Professor in the College of Information Science and Systems Engineering at the University of Arkansas at Little Rock.

\section{ACKNOWLEDGEMENTS}

This material is based upon the work supported by the National Science Foundation under Grant No. EEC-0230601, Bridges for Engineering Education (BEE). 